\title{
EFFECTS OF POTASSIUM HUMATE ON COTTON (GOSSYPIUM HIRSUTUM L.) GROWTH AND YIELD AND SOIL SALINITY UNDER FILM-MULCHED DRIP IRRIGATION WITH BRACKISH WATER IN NORTHWEST CHINA
}

\author{
WEI, K. - ZHANG, J. H. - WANG, Q. J. ${ }^{*}$ - CHEN, Y. - GUO, Y. - Sun, Y. \\ State Key Laboratory Base of Eco-hydraulic Engineering in Arid Area, Xi'an University of \\ Technology, 5 Jinhua South Road, Beilin District, Xi 'an, China \\ (phone: +86-8231-2598; fax: +86-8231-2504) \\ *Corresponding author \\ e-mail:18291869766@163.com
}

(Received 21 $1^{\text {st }}$ Apr 2021; accepted 19 ${ }^{\text {th }}$ Jul 2021)

\begin{abstract}
Soil salinity and poor soil structure are the main limitations of the agricultural economy in arid areas. The objectives of this study were to investigate the effects of different potassium humate amounts on cotton growth, seed cotton yield, water use efficiency and soil salinity under film-mulched drip irrigation with brackish water. The results showed potassium humate affected salt accumulation and the salt accumulation rate of potassium humate treatments $\left(2.5,5,10,15,20\right.$, and $\left.30 \mathrm{~kg}^{-h^{-1}}\right)$ within $0-40 \mathrm{~cm}$ soil depths was $63.0 \%, 67.9 \%, 68.9 \%, 70.5 \%, 75.4 \%$, and $100 \%$ lower than the untreated soils. Potassium humate application significantly enhanced the proportion of soil macro-aggregates and the mean weight diameter of water-stable aggregates. Potassium humate significantly increased cotton stem diameter, boll number per plant, plant height, and leaf area index compared to the control. Furthermore, the cotton yield and water use efficiency increased significantly. The potassium humate application amount of $20.5 \mathrm{~kg} \mathrm{ha}^{-1}$ was recommended as an optimal potassium humate amount of saline soils from the point of view of water saving. The potassium humate application amount of $30 \mathrm{~kg} \cdot \mathrm{ha}^{-1}$ was recommended as an optimal potassium humate amount of saline soils from the point of view of improving soil quality.
\end{abstract}

Keywords: salt leaching efficiency, soil aggregates, mean weight diameter, water use efficiency, growth degree-days

\section{Introduction}

Cotton is the most important renewable natural textile fiber worldwide and the world's sixth-largest source of vegetable oil (Shareef et al., 2018; Zhao et al., 2020). Therefore, optimizing crop productivity is important for sustainable food, feed, fuel, and fiber supplies for the growing human population (Watts et al., 2017). With economic development and population growth, the demand for fresh water resources is gradually increasing (Du et al., 2020).

Water for irrigation is a major limitation to agricultural production in the Xinjiang region. The Xin Jiang region in Northwest China is one of the most important cotton producers. The cotton plantation area in Xinjiang is $1.8 \times 10^{6}$ ha, accounting for $54 \%$ of China's total cotton planting area (Kuang et al., 2018). It produced $451 \times 10^{4} \mathrm{t}$ of cotton (Gossypium hirsutum L.) in 2014, accounting for $73 \%$ of China's total cotton production (Tian et al., 2017). Meanwhile, surface water evaporation caused by high temperatures results in a severe water shortage in southern Xinjiang leading to soil salinization, a lowered survival rate for crops, and slow development of local agriculture (Fang et al., 2019). Brackish water can bridge the water supply gap. However, increased use of brackish water for irrigation exacerbates the soil salinization problems, and reduce crop yield (Mahmoodi-Eshkaftaki and Rafiee, 2020; Sekhon et al., 2020). 
Moreover, soil salinity is one of the most widespread soil degradation processes worldwide and China has the third-largest area of saline-alkali soil (Nan et al., 2020). The global area of saline-alkali soils is approximately 900 million ha (Rath et al., 2019). In China, approximately 3.67 million ha of soil, which represents $4.88 \%$ of the total available land across the country, is threatened by salt ( $\mathrm{Li}$ et al., 2014). The accumulation of salt can directly decrease soil nutrient efficiency by inhibiting microbial mineralization activity in saline soil (Rath and Rousk, 2015). Additionally, salinity can also indirectly affect soil nutrient cycling and efficiency by destroying soil physical structure (Lakhdar et al., 2009; Zhang et al., 2015). High salinity, soil structure degradation, and nutrient deficiencies are the three characteristics of saline-alkali soil that inhibit plant growth and decrease crop yields (Zheng et al., 2018). Thus, the improvement of saline-alkali soil has attracted widespread attention.

Potassium widely exists in peat, lignite and weathered coal, an organic macromolecule with good biological activity. Potassium humate has been reported as a practical and economical option to improve degraded land resources. Furthermore, potassium humate is a common organic fertilizer that can improve soil structure and influence soil microbial activity, thus improving salt-affected soil fertility (Ouni et al., 2014). Khaled et al. (2011) studied the effects of the application of humic acid gradient on soil nutrient content, soil properties and maize growth in saline-alkali land, and found that application of $2 \mathrm{~g} \cdot \mathrm{kg}^{-1}$ soil humic acid reduced maize's absorption of nitrogen and increased the dry matter weight of maize under salt stress. Ahmed et al. (2020) informed that the application of potassium humate could reduce nitrogen loss in soil. Izhar et al. (2020) found that the application of humic acid can improve crop yield and phosphorus uptake in calcareous soils. Saidimoradi et al. (2019) explored that inclusion of humic acid in the nutrient solution of hydroponically grown strawberry improved plant responses to salinity. Nonetheless, further study is still needed to understand better the effects of potassium humate on cotton in arid-saline soil under conjunctive brackish water irrigation. The present study was conducted to exploit the potential of potassium humate as a treatment for low quality soil and water resources used in cotton production in the Xinjiang region of Northwest China. The primary objectives are to investigate: (1) cotton plant height, leaf area index, aboveground biomass, and yield; (2) soil salinity; (3) the optimal application amount of potassium humate.

\section{Materials and methods}

\section{Site description}

Field studies were conducted during 2019 at the Bazhou Irrigation Experiment

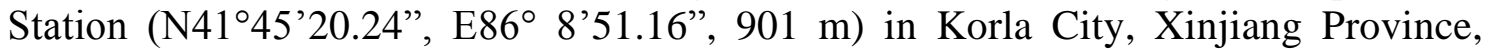
Northwest China. Korla is warm temperate zone with an arid continental arid climate. It has a $226 \mathrm{~d}$ frost-free period with $3036 \mathrm{~h}$ sunshine hours. The average annual potential evaporation is $2278.2 \mathrm{~mm}$. During the cotton growing season, the long-term average annual temperature and precipitation are $22.5^{\circ} \mathrm{C}$ and $70 \mathrm{~mm}$. Characteristics of the daily weather conditions, including daily precipitation and average air temperature, are shown in (Fig. 1). The weather data were obtained from the field using an automatic meteorological station. The average temperature in the cotton growth period (April-September) was $24.2{ }^{\circ} \mathrm{C}$, and the total precipitation in this period was $64.4 \mathrm{~mm}$. 
The soil was classified as sandy loam with an average particle size distribution of approximately $41.4 \%$ sand, $54.4 \%$ silt and $4.2 \%$ clay (USDA, 2020), with an average soil bulk density of $1.54 \mathrm{~g} \cdot \mathrm{cm}^{-3}$, a $\mathrm{pH}$ of $8.75,76.8 \mathrm{mg} \cdot \mathrm{kg}^{-1}$ of total organic matter, $3.92 \mathrm{mg} \cdot \mathrm{kg}^{-1}$ of total nitrogen, $31.1 \mathrm{mg} \cdot \mathrm{kg}^{-1}$ of available phosphorus of and $72.0 \mathrm{mg} \mathrm{kg}{ }^{-1}$ of available potassium. The groundwater depth is over $7 \mathrm{~m}$. The electronic conductivity (EC) of groundwater is $2.73-2.95 \mathrm{~ms}^{\cdot} \mathrm{cm}^{-1}$. The total dissolved solids of groundwater is $2.2 \mathrm{~g} \cdot \mathrm{L}^{-1}$. A comprehensive list of the and the chemical properties of groundwater is given in Table 1 .

Table 1. The chemical properties of groundwater during the cotton growing season

\begin{tabular}{c|c|c|c|c|c|c|c|c}
\hline Properties & $\mathbf{p H}$ & $\begin{array}{c}\mathbf{H C O}^{3-} \\
\left(\mathbf{g} \cdot \mathbf{L}^{-1}\right)\end{array}$ & $\begin{array}{c}\mathbf{C l}^{-} \\
\left(\mathbf{g} \cdot \mathbf{L}^{-1}\right)\end{array}$ & $\begin{array}{c}\mathbf{S O}^{\mathbf{}^{-}} \\
\left(\mathbf{g} \cdot \mathbf{L}^{-1}\right)\end{array}$ & $\begin{array}{c}\mathbf{C a}^{2+} \\
\left(\mathbf{g} \cdot \mathbf{L}^{-1}\right)\end{array}$ & $\begin{array}{c}\mathbf{M g}^{++} \\
\left(\mathbf{g} \cdot \mathbf{L}^{-1}\right)\end{array}$ & $\begin{array}{c}\mathbf{K}^{+} \\
\left(\mathbf{g} \cdot \mathbf{L}^{-1}\right)\end{array}$ & $\begin{array}{c}\mathbf{N a}^{+} \\
\left(\mathbf{g} \cdot \mathbf{L}^{-1}\right)\end{array}$ \\
\hline Value & 7.38 & 0.401 & 0.335 & 1.110 & 0.227 & 0.149 & 0.029 & 0.369 \\
\hline
\end{tabular}

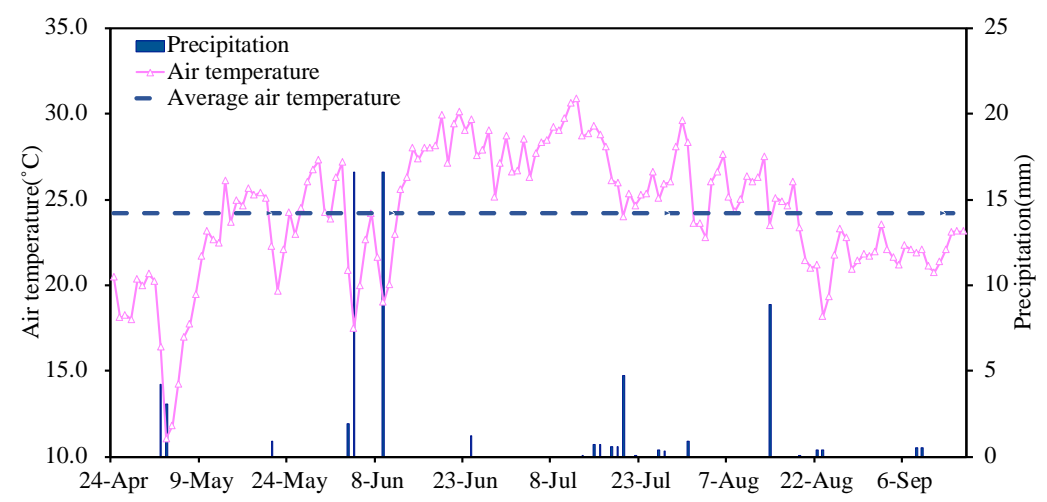

Figure 1. Daily air temperature and precipitation during the cotton growing seasons

\section{Experimental treatments and design}

A drip irrigation system under film mulch was selected as the method of cultivation. The experiments consisted of seven application levels $(0,2.5,5,10,15,20$, and 30 $\mathrm{kg} \cdot \mathrm{ha}^{-1}$ ) of potassium humate. The CK, HA1, HA2, HA3, HA4, HA5 and HA6 treatments represented $0,2.5,5,10,15,20$, and $30 \mathrm{~kg} \cdot \mathrm{ha}^{-1}$ of potassium humate, respectively. The water-soluble potassium humate was uniformly sprayed on the soil surface of each plot, and then plowed from the surface to $30 \mathrm{~cm}$ using a rotary cultivator. Therefore, the depth of the soil layer mixed with biochar was $0-30 \mathrm{~cm}$. The treatments were replicated three times in a randomized block design. The irrigation schedule for cotton in Xinjiang is shown in Table 2.

A $16 \mathrm{~mm}$ diameter inlaid, thin-walled, labyrinth drip line was used for irrigation. The average discharge of the emitters was $30 \mathrm{~cm}$, while the cotton plants along each row were spaced $10 \mathrm{~cm}$ apart. Water meters and ball valves were installed to control the amount of water applied to each plot. Each field plot was $5.6 \mathrm{~m}$ wide and $10 \mathrm{~m}$ long.

Urea and potassium dihydrogen phosphate were used as fertilizer, which were applied to the fields at 14 different times. Except for the early cotton growth, each fertilizer application occurred by drip irrigation during the middle of each irrigation stage. Differential pressure tanks with $25 \mathrm{~L}$ capacity were used for fertilizers. The solid fertilizers were dissolved in the water one day before irrigation. 
Table 2. Irrigation scheduling for cotton in Xinjiang

\begin{tabular}{c|c|c|c|c}
\hline Irrigation time & Irrigation date & $\begin{array}{c}\text { Cotton growing } \\
\text { stage }\end{array}$ & BBCH scale & $\begin{array}{c}\text { Irrigation amount } \\
(\mathbf{m m})\end{array}$ \\
\hline 1 & 18-June & & & 30 \\
2 & 23-June & Seedling and & $1-59$ & 30 \\
3 & 29-June & squaring stage & & 30 \\
4 & 4-July & & & 30 \\
5 & 11-July & & & 30 \\
\hline 6 & 16-July & & & 30 \\
7 & 21-July & Flowering stage & $60-69$ & 30 \\
8 & 26-July & & & 30 \\
\hline 9 & 1-Aug & & & 30 \\
10 & 6-Aug & & & 37.5 \\
11 & 11-Aug & Bolls and boll- & & 37.5 \\
12 & 16-Aug & opening stage & & 37.5 \\
13 & 21-Aug & & & 37.5 \\
14 & 26-Aug & & & 37.5 \\
15 & 31-Aug & & & 487.5 \\
\hline Total & \multicolumn{3}{|l}{} \\
\hline
\end{tabular}

Cotton was planted following the cultivation mode of plastic film mulching with short rod dense planting (Fig. 2). The system was installed with a row configuration of $20 \mathrm{~cm}+40 \mathrm{~cm}+20 \mathrm{~cm}$ (narrow-wide-narrow). Two driplines were installed for four rows under a $1 \mathrm{~m}$-wide film. The distance between the two films was $60 \mathrm{~cm}$.

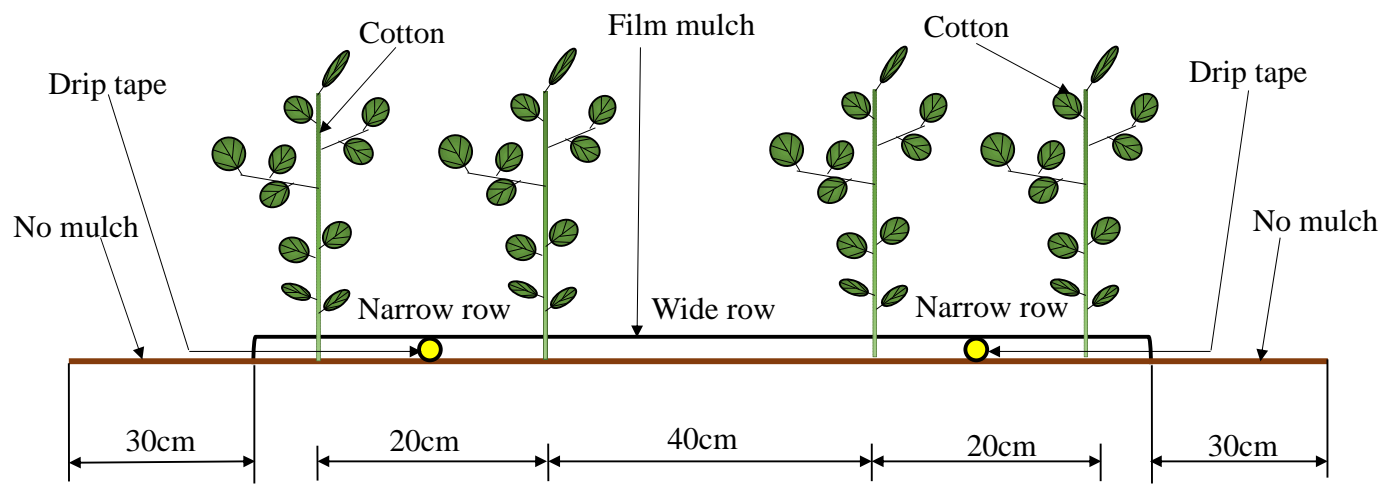

Figure 2. The relative positions of row spacing, dripline, and plastic film

\section{Measurements and calculations}

Leaf area and leaf area index

At the seedling stage, bud stage, flowering phase, fluid phase and boll-opening stage, four plants were randomly selected from each plot, and the length and width of each leaf on the plants were measured using a tape measure to obtain the leaf area (Kumar et al., 2020).

The green leaf area plant of the plant was calculated using the following equation: 


$$
L A=\sum_{i}^{n} a_{i} \times b_{i} \times 0.703
$$

where LA represents the leaf area for the single cotton plant $\left(\mathrm{cm}^{2}\right), a_{i}(\mathrm{~cm})$ and $b_{i}(\mathrm{~cm})$ were length and width of one green leaf, $n$ is the number leaf per plant and 0.703 is the correction factor for the cotton crop (Tan, 2018).

The leaf area index (LAI) was then calculated as follow (Wang et al., 2018; Watson, 1937):

$$
L A=L A I / S_{O}
$$

where $\mathrm{LA}_{\mathrm{T}}$ represents the total area of the leaf $\left(\mathrm{cm}^{2}\right)$, and $\mathrm{S}_{\mathrm{O}}$ represents the occupied land area $\left(\mathrm{cm}^{2}\right)$.

\section{Aboveground dry matter accumulation}

At the seedling stage, bud stage, flowering phase, fluid phase and boll-opening stage, four plant were randomly selected from each plot. The leaves, stem, and bolls were placed into an oven at $105{ }^{\circ} \mathrm{C}$ for $30 \mathrm{~min}$ and then dried at $75{ }^{\circ} \mathrm{C}$ to a constant weight.

A logistic regression model was fitted to describe cotton aboveground biomass (Khan et al., 2017).

$$
A M=\frac{A M_{M A X}}{1+e^{(a-b * G D D)}}
$$

where GDD $\left({ }^{\circ} \mathrm{C}\right)$ is the growing degree-days after sowing, $\mathrm{AM}(\mathrm{g})$ is the aboveground biomass, $\mathrm{AM}_{\max }(\mathrm{g})$ is the maximum aboveground biomass and $\mathrm{a}$ and $\mathrm{b}$ are the constants to be assessed.

Growing degree-days (GDD), are frequently used to describe the timing of biological processes. The basic equation as follows (Mcmaster and Wilhelm, 1997):

$$
G D D=\left[\left(T_{M A X}+T_{M I N}\right) / 2\right]-T_{B A S E}
$$

where $\mathrm{T}_{\mathrm{MAX}}$ and $\mathrm{T}_{\mathrm{MIN}}$ are daily maximum and minimum air temperature, respectively, and $\mathrm{T}_{\mathrm{BASE}}$ is the base temperature of cotton $\left(10^{\circ} \mathrm{C}\right)$.

Based on Equation 1, the following equations were calculated:

$$
\begin{aligned}
G D D_{1} & =\frac{a-\ln (2+\sqrt{3})}{b} \\
G D D_{1} & =\frac{a-\ln (2-\sqrt{3})}{b} \\
V & =\frac{b * A M_{\text {max }}}{4}
\end{aligned}
$$




$$
G D D_{3}=\frac{a}{b}
$$

where $\mathrm{V}\left(\mathrm{g} \cdot{ }^{\circ} \mathrm{C}\right)$ is the highest aboveground biomass rate, $\mathrm{GDD}_{3}\left({ }^{\circ} \mathrm{C}\right)$ is the growing degree days of largest aboveground biomass accumulation, which initiates at temperature $\mathrm{GDD}_{1}$ and terminates at $\mathrm{GDD}_{2}$.

\section{Crop evapotranspiration calculations}

During the growth of cotton, crop evapotranspiration (water consumption) could be calculated via the water balance equation as follows (Zhou et al., 2019):

$$
E T_{c}=P+I+G+\Delta W-R_{0}-F
$$

where $\mathrm{ET}_{\mathrm{c}}$ is crop evapotranspiration also called water consumption $(\mathrm{mm})$; $\mathrm{P}$ is precipitation in the growing period $(\mathrm{mm})$; I is irrigation $(\mathrm{mm}) ; \mathrm{G}$ is groundwater recharge $(\mathrm{mm}) ; \Delta \mathrm{W}$ was calculated as change in soil water storage in the $0-100 \mathrm{~cm}$ soil layer from sowing to maturity $(\mathrm{mm}) ; \mathrm{R}_{0}$ is surface runoff $(\mathrm{mm}) ; \mathrm{F}$ is deep percolation $(\mathrm{mm})$. The water table in the experimental-area was below $7 \mathrm{~m}$. Rainfall was very scarce during the growing cotton period; hence the $G, R_{0}$, and $F$ could be negligible in this research, respectively. Therefore, the equation can be written as follows:

$$
E T_{c}= \pm \Delta W+P+I
$$

\section{Soil salinity content and salt accumulation}

Soil samples were collected to measure soil salinity content at a $10 \mathrm{~cm}$ interval from 0 to $40 \mathrm{~cm}$ and at a $20 \mathrm{~cm}$ interval from 40 to $100 \mathrm{~cm}$ with using an auger $(5 \mathrm{~cm}$ diameter). All collected soil samples were air-dried, sieved through a $1 \mathrm{~mm}$ sieve, and then were used for preparing dilute soil extract solutions based on extract solutions based on extracts with a 1:5 soil-water ratio. Salt concentrations were inferred from the measured electrical conductivity (EC) values (Tan et al., 2018).

$$
S C=E C_{1: 5} \times 4.25
$$

where SC is the soil salinity content $\left(\mathrm{g} \cdot \mathrm{kg}^{-1}\right)$ and the number 4.25 is a conversion factor used to convert $\mathrm{EC}_{1: 5}$ extract to mass salt per unit mass of soil.

The salt balance in an irrigated field zone over a time interval is related to the salt inputs and outputs (Ning et al., 2020).

$$
\Delta S=S_{2}-S_{1}=S_{R}+S_{I}+S_{G}+S_{F}-S_{C}-S_{P}-S_{D}
$$

where $\Delta \mathrm{S}(\mathrm{g})$ is the change of salt storage in the soil; $\mathrm{S}_{1}(\mathrm{~g})$ is the salt content in the soil before sowing; $S_{2}(g)$ is the salt content in the soil after harvesting; $S_{R}, S_{I}, S_{G}$ and $S_{F}$ are salt concentration during precipitation, irrigation, groundwater, and fertilizer; $S_{C}$ is the salt uptake by the crop; $S_{P}$ is the total removal of salts by absorption, precipitation and transformation; and $\mathrm{S}_{\mathrm{D}}$ is the salt carried away by underground drainage or seepage. The 
groundwater level of the experimental field is $7 \mathrm{~m}$ and $\mathrm{So}_{\mathrm{G}}, \mathrm{S}_{\mathrm{P}}, \mathrm{S}_{\mathrm{D}}$ equals cero. The $\mathrm{S}_{\mathrm{C}}$ and $S_{P}$ are also small and negligible.

\section{Soil aggregate stability}

Moreover, at harvesting stage, soil samples were collected from each experimental plot with an auger in 0-15 cm soil layer, and passed through a 2-mm sieve and soil samples were analyzed by wet sieving method (Nie et al., 2018). Water-stable aggregates were classified as the three different aggregate size fractions: $2-1 \mathrm{~mm}, 1-0.25 \mathrm{~mm}$ and $<0.25$ $\mathrm{mm}$ fractions. Each fraction was weighed to calculate the dry aggregate stability expressed by mean weight diameter (MWD). The MWD was calculated from the mass fraction of soil remaining on each sieve as (Sheehy et al., 2015):

$$
M D W=\sum_{i=1}^{n} A_{i} * W_{i}
$$

where $A_{i}$ is the mean diameter of the three aggregate size classes; $\mathrm{W}_{\mathrm{i}}$ is the mass proportion of aggregate size classes remaining on each sieve.

\section{Data analysis}

The value of each indicator was the mean of three replicates per treatment, and the SPSS statistics v.22 (IBM, Inc, Chicago, IL, USA) was used to perform analysis of variance. All pair-wise comparisons of the treatment means were performed using the least significant difference (LSD) test with significance determined at the 5\% level.

\section{Results}

\section{Soil salinity}

We defined the desalination rate as $\mathrm{DR}=\Delta \mathrm{S} / \mathrm{S}_{\mathrm{i}} \times 100 \%$. In this study, the salt accumulation rate of CK, HA1, HA2, HA3, HA4 and HA5 treatments were $40.3 \%$, $14.9 \%, 12.9 \%, 12.5 \%, 11.9 \%$ and $9.9 \%$ for the $0-40 \mathrm{~cm}$ depth range, respectively. The desalination rate of HA6 treatment was $42.7 \%$ for $0-40 \mathrm{~cm}$ the depth range. At the 0$100 \mathrm{~cm}$ depth range the deposition rate of CK, HA1, HA2, HA3, HA4, HA5 and HA6 treatments were $56.4 \%, 14.2 \%, 39.4 \%, 58.2 \%, 14.6 \%, 12.1 \%$ and $9.8 \%$, respectively (Table 3).

\section{Water-stable aggregates and mean weight diameter (MWD)}

The proportion of soil micro-aggregates $(<0.25 \mathrm{~mm})$ was significant lower in HA2, HA3, HA4, HA5 and HA6 treatments than that of the CK $(P<0.01)$. However, potassium humate treatments significantly increased the proportion of large soil macroaggregates $(2-1 \mathrm{~mm})$ and small soil macro-aggregates compared with the CK (1$0.25 \mathrm{~mm})(P<0.01)$. This showed that application of potassium humate could enhance formation of soil macro-aggregates $(0.25-2 \mathrm{~mm})$. Moreover, the mean weight diameter of soil aggregates was significantly $(P<0.01)$ higher in potassium humate treatments than that of the $\mathrm{CK}$, which indicated application of potassium humate increased the stability of soil aggregates. Hence, potassium humate application was effective in improving the quality of saline soil (Table 4). 
Table 3. Salt accumulation and salt-leaching efficiency at $0-40 \mathrm{~cm}$ and $0-100 \mathrm{~cm}$ soil depth for different potassium humate application treatments

\begin{tabular}{c|c|c|c|c|c}
\hline $\begin{array}{c}\text { Soil depth } \\
(\mathbf{c m})\end{array}$ & Treatments & $\mathbf{S}_{\mathbf{i}}\left(\mathbf{g} \cdot \mathbf{m}^{-\mathbf{2}}\right)$ & $\Delta \mathbf{S}\left(\mathbf{g} \cdot \mathbf{m}^{-2}\right)$ & $\begin{array}{c}\text { Accumulation } \\
\text { rate }(\boldsymbol{\%})\end{array}$ & $\begin{array}{c}\text { Desalination rate } \\
(\boldsymbol{\%})\end{array}$ \\
\hline \multirow{5}{*}{$0-40$} & CK & $425.8 \pm 26.3 \mathrm{f}$ & $287.6 \pm 7.5 \mathrm{~b}$ & $40.3 \pm 0.02 \mathrm{a}$ & - \\
& HA1 & $2238.7 \pm 39.3 \mathrm{~b}$ & $393.5 \pm 13.8 \mathrm{a}$ & $14.9 \pm 0.01 \mathrm{~b}$ & - \\
& HA2 & $552.2 \pm 20.6 \mathrm{e}$ & $82.1 \pm 57.1 \mathrm{e}$ & $12.9 \pm 0.08 \mathrm{~b}$ & - \\
& HA3 & $297.7 \pm 44.9 \mathrm{~g}$ & $42.7 \pm 32.0 \mathrm{e}$ & $12.5 \pm 0.1 \mathrm{~b}$ & - \\
& HA4 & $1715.7 \pm 35.6 \mathrm{c}$ & $232.1 \pm 45.1 \mathrm{c}$ & $11.9 \pm 0.02 \mathrm{~b}$ & - \\
& HA5 & $1546.2 \pm 37.3 \mathrm{~d}$ & $170.8 \pm 17.1 \mathrm{~d}$ & $9.9 \pm 0.01 \mathrm{~b}$ & - \\
& HA6 & $3643.9 \pm 36.5 \mathrm{a}$ & $-1089.8 \pm 10.8 \mathrm{f}$ & - & $-42.7 \pm 0.01 \mathrm{~d}$ \\
\hline \multirow{5}{*}{$0-100$} & CK & $872.2 \pm 77.5 \mathrm{E}$ & $1129.9 \pm 135.0 \mathrm{~A}$ & $56.4 \pm 0.05 \mathrm{~A}$ & - \\
& HA1 & $6224.9 \pm 277.6 \mathrm{~B}$ & $1033.0 \pm 16.9 \mathrm{~A}$ & $14.2 \pm 0.01 \mathrm{CD}$ & - \\
& HA2 & $1557.1 \pm 50.3 \mathrm{D}$ & $1015.1 \pm 35.5 \mathrm{~A}$ & $39.4 \pm 0.01 \mathrm{~B}$ & - \\
& HA3 & $698.8 \pm 53.2 \mathrm{E}$ & $875.9 \pm 77.2 \mathrm{~B}$ & $20.2 \pm 0.03 \mathrm{~A}$ & - \\
& HA4 & $4440.9 \pm 163.9 \mathrm{C}$ & $763.1 \pm 59.8 \mathrm{~B}$ & $14.6 \pm 0.01 \mathrm{C}$ & - \\
& HA5 & $4307.4 \pm 253.2 \mathrm{C}$ & $594.8 \pm 110.4 \mathrm{C}$ & $12.1 \pm 0.02 \mathrm{CD}$ & - \\
& HA6 & $7518.7 \pm 245.7 \mathrm{~A}$ & $818.0 \pm 77.4 \mathrm{~B}$ & $9.8 \pm 0.01 \mathrm{D}$ & - \\
\hline
\end{tabular}

Data are mean of the three replicates. The different lowercase letters indicate significant differences between treatments of $0-40 \mathrm{~cm}$ depth at $\mathrm{P}<0.05$ level according to the LSD test; the same letters are not significantly different at $\mathrm{P}>0.05$ level according to the LSD test. The different capital letters indicate significant differences between treatments of $0-100 \mathrm{~cm}$ depth at $\mathrm{P}<0.05$ level according to the LSD test; the same letters are not significantly different at $\mathrm{P}>0.05$ level according to the LSD test

Table 4. Effects of different potassium humate amounts on water-stable aggregates distribution and mean weight diameter (MWD) in 0-15 cm soil layer

\begin{tabular}{|c|c|c|c|c|}
\hline Treatments & $2-1 \mathrm{~mm}(\%)$ & 1-0.25 mm (\%) & $<0.25 \mathrm{~mm}(\%)$ & MWD (mm) \\
\hline $\mathrm{CK}$ & $15.44 \pm 1.36 \mathrm{e}$ & $37.31 \pm 0.97 \mathrm{de}$ & $47.25 \pm 0.41 \mathrm{a}$ & $0.53 \pm 0.02 f$ \\
\hline HA1 & $16.22 \pm 1.16 \mathrm{e}$ & $36.53 \pm 1.69 \mathrm{e}$ & $47.25 \pm 2.54 \mathrm{a}$ & $0.53 \pm 0.02 f$ \\
\hline HA2 & $19.35 \pm 0.75 \mathrm{~d}$ & $39.03 \pm 0.92 \mathrm{cde}$ & $41.62 \pm 1.67 b$ & $0.59 \pm 0.02 \mathrm{e}$ \\
\hline HA3 & $21.48 \pm 1.34 \mathrm{~cd}$ & $40.23 \pm 1.04 \mathrm{bcd}$ & $38.29 \pm 2.38 b$ & $0.62 \pm 0.03 \mathrm{~d}$ \\
\hline HA4 & $23.71 \pm 0.61 b c$ & $42.21 \pm 1.03 b c$ & $34.09 \pm 0.76 c$ & $0.66 \pm 0.01 c$ \\
\hline HA5 & $26.20 \pm 1.63 \mathrm{ab}$ & $43.48 \pm 2.93 b$ & $30.32 \pm 3.13 d$ & $0.70 \pm 0.03 b$ \\
\hline HA6 & $27.43 \pm 2.51 \mathrm{a}$ & $47.30 \pm 2.71 \mathrm{a}$ & $25.26 \pm 1.68 \mathrm{e}$ & $0.74 \pm 0.03 a$ \\
\hline Source of variance & & & & \\
\hline Potassium humate & $* *$ & $* *$ & $* *$ & $* *$ \\
\hline
\end{tabular}

Data are mean of the three replicates. The different letters indicate significant differences between treatments at $\mathrm{P}<0.05$ level according to the LSD test; the same letters are not significantly different at $\mathrm{P}>0.05$ level according to the LSD test. $* *$ indicates significant differences between treatments at $\mathrm{P}<0.01$

\section{Plant stem diameter, plant height, leaf area index and aboveground biomass}

Stem diameter increased first and then stabilized with the increase of growing degree days. Stem diameter increased rapidly between $742{ }^{\circ} \mathrm{C}$ and $1096{ }^{\circ} \mathrm{C}$. The stem diameter in each treatment was as follows: HA5 $>$ HA $4>\mathrm{HA} 1>\mathrm{HA} 2>\mathrm{HA} 6>\mathrm{HA} 3>\mathrm{CK}$. The 
maximum stem diameter was obtained in HA5 treatment. HA5 treatment significantly increased the stem diameter compared to CK $(\mathrm{P}<0.05)$. HA5 treatment increased stem diameter by $9.3 \%, 10.5 \%, 6.4 \%, 8.2 \%, 1.3 \%$ and $10.7 \%$, compared to CK, HA1, HA2, HA3, HA4 and HA6, respectively (Fig. $3 a$ ). Potassium humate treatments significantly affected plant height $(\mathrm{P}<0.05)$. Plant height increased first and then stabilized with the increasing of growing degree days. The plant height in HA1, HA2, HA3, HA4, HA5 and HA6 treatments increased $6.22 \%, 12.98 \%, 16.93 \%, 19.48 \%, 18.82 \%$ and $20.65 \%$, respectively, compared to $\mathrm{CK}$ treatment (Fig. 3b). The maximum plant height was obtained in HA6 treatment.
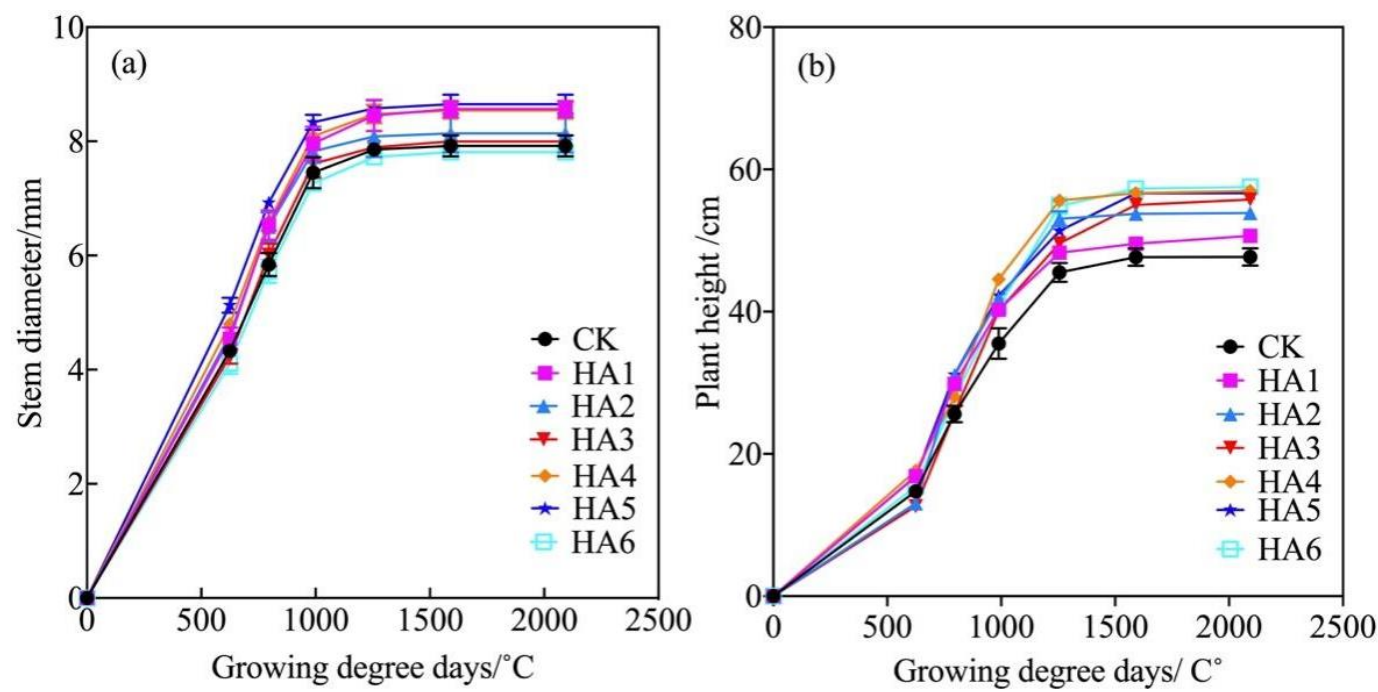

Figure 3. Effect of potassium humate application on stem diameter and plant height during the cotton growth period. Bars are the means + one standard error of the mean $(n=3)$

The leaf area index increased first and then decreased with the increase of growing degree days. Leaf area index in HA1, HA2, HA3, HA4, HA5 and HA6 treatments significantly increased $0.73 \%, 4.3 \%, 7.8 \%, 7.6 \%, 11.7 \%$ and $16.8 \%$, respectively, compared to $\mathrm{CK}$ treatment $(\mathrm{P}<0.05)$. The maximum leaf area index was obtained in the HA6 treatment (Fig. 4a). The aboveground biomass accumulation increased following a normal logistic function by growing degree days (Fig. 4b). The aboveground biomass in HA1, HA2, HA3, HA4, HA5 and HA6 significantly increased 5.96\%, 10.13\%, 19.73\%, $25.53 \%, 30.28 \%$ and $36.29 \%$, respectively, compared to $\mathrm{CK}$ treatment $(\mathrm{P}<0.05)$. The maximum aboveground biomass was obtained in HA6 treatment.

\section{Simulation of biomass accumulation}

Simulation of aboveground biomass with growing degree days (GDD) was assessed using Equation 3 and the result are shown in Tables 5 and 6. The logistic function was followed by aboveground biomass accumulation as a sigmoidal growth pattern, although they differed in equation coefficients among treatments. Calculation by Equations 4-6 showed the beginning and termination at fast accumulation growing degree-days for cotton aboveground biomass accumulation. HA6 began the fast accumulation growing degree days at $1002.0^{\circ} \mathrm{C}$ and ended at $1677.5^{\circ} \mathrm{C}$, and maximum $\left(0.09 \mathrm{~g} \cdot{ }^{\circ} \mathrm{C}^{-1}\right)$ rates at 1339.8 compared with other treatment (Table 6). 

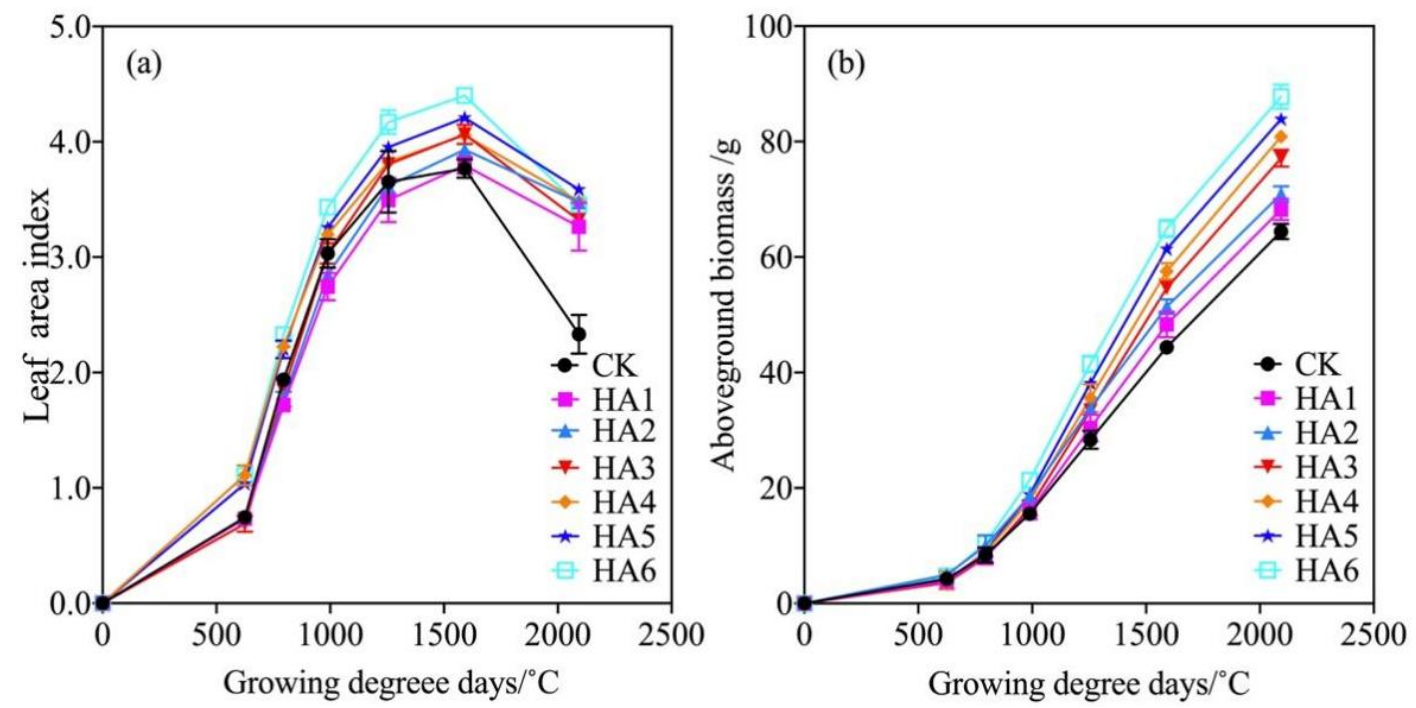

Figure 4. Effect of potassium humate application on leaf area index and aboveground biomass during the cotton growth period. Bars are the means + one standard error of the mean $(n=3)$

Table 5. Parameters $\left(A M_{\max }, a, b\right)$ of the logistic model of dry matter accumulation for each treatment

\begin{tabular}{c|c|c|c}
\hline Treatments & $\mathbf{A M}_{\max } / \mathbf{g}$ & $\mathbf{a}$ & $\mathbf{b}$ \\
\hline CK & $70.29 \pm 2.26 \mathrm{e}$ & $4.7448 \pm 1.30 \mathrm{~b}$ & $0.0034 \pm 0.0010 \mathrm{~b}$ \\
HA1 & $72.81 \pm 1.45 \mathrm{de}$ & $5.0743 \pm 0.35 \mathrm{a}$ & $0.0037 \pm 0.0002 \mathrm{ab}$ \\
HA2 & $75.84 \pm 1.39 \mathrm{~d}$ & $4.7309 \pm 0.18 \mathrm{ab}$ & $0.0035 \pm 0.0001 \mathrm{ab}$ \\
HA3 & $81.54 \pm 1.49 \mathrm{c}$ & $5.3981 \pm 0.20 \mathrm{a}$ & $0.0039 \pm 0.0002 \mathrm{ab}$ \\
HA4 & $85.61 \pm 1.20 \mathrm{~b}$ & $5.2951 \pm 0.40 \mathrm{a}$ & $0.0039 \pm 0.0011 \mathrm{ab}$ \\
HA5 & $87.86 \pm 1.41 \mathrm{~b}$ & $5.4497 \pm 0.22 \mathrm{a}$ & $0.0041 \pm 0.0002 \mathrm{a}$ \\
HA6 & $92.06 \pm 2.65 \mathrm{a}$ & $5.2251 \pm 0.19 \mathrm{a}$ & $0.0039 \pm 0.0002 \mathrm{ab}$ \\
\hline
\end{tabular}

Data are mean of the three replicates. The different letters indicate significant differences between treatments at $\mathrm{P}<0.05$ level according to the LSD test; the same letters are not significantly different at $\mathrm{P}>0.05$ level according to the LSD test

Table 6. Parameters (GDD1, GDD2, V, GDD) of the logistic model of dry matter accumulation for each treatment

\begin{tabular}{c|c|c|c|c}
\hline Treatments & $\mathbf{G D D}_{1} /{ }^{\circ} \mathbf{C}$ & $\mathbf{G D D}_{2} /{ }^{\circ} \mathbf{C}$ & $\mathbf{V} / \mathbf{g} \cdot{ }^{\circ} \mathbf{C}^{-\mathbf{1}}$ & $\mathbf{G D D} /{ }^{\circ} \mathbf{C}$ \\
\hline CK & $1008.2 \pm 176.7 \mathrm{a}$ & $1782.9 \pm 29.0 \mathrm{a}$ & $0.060 \pm 0.022 \mathrm{~b}$ & $1395.6 \pm 30.3 \mathrm{a}$ \\
HA1 & $1015.5 \pm 48.9 \mathrm{a}$ & $1727.4 \pm 39.9 \mathrm{a}$ & $0.067 \pm 0.005 \mathrm{ab}$ & $1371.4 \pm 40.3 \mathrm{a}$ \\
$\mathrm{HA} 2$ & $975.4 \pm 19.3 \mathrm{a}$ & $1728.0 \pm 10.3 \mathrm{a}$ & $0.066 \pm 0.003 \mathrm{ab}$ & $1351.7 \pm 10.1 \mathrm{a}$ \\
HA3 & $1046.4 \pm 11.3 \mathrm{a}$ & $1721.8 \pm 17.1 \mathrm{a}$ & $0.079 \pm 0.004 \mathrm{ab}$ & $1384.1 \pm 6.5 \mathrm{a}$ \\
HA4 & $1020.0 \pm 65.2 .8 \mathrm{a}$ & $1695.4 \pm 10.1 \mathrm{a}$ & $0.083 \pm 0.026 \mathrm{ab}$ & $1357.7 \pm 12.5 \mathrm{a}$ \\
HA5 & $1008.0 \pm 15.5 \mathrm{a}$ & $1650.4 \pm 10.0 \mathrm{a}$ & $0.090 \pm 0.004 \mathrm{ab}$ & $1329.2 \pm 4.3 \mathrm{a}$ \\
HA6 & $1002.1 \pm 11.1 \mathrm{a}$ & $1677.5 \pm 18.8 \mathrm{a}$ & $0.090 \pm 0.004 \mathrm{a}$ & $1339.8 \pm 8.5 \mathrm{a}$ \\
\hline
\end{tabular}

Data are mean of the three replicates. The different letters indicate significant differences between treatments at $\mathrm{P}<0.05$ level according to the LSD test; the same letters are not significantly different at $\mathrm{P}>0.05$ level according to the LSD test 


\section{Boll weight, boll number, seed cotton yield and water use efficiency}

Boll weight of HA1, HA2, HA3, HA4, HA5 and HA6 increased 5.1\%, 11.2\%, 7.8\%, $11.2 \%, 16.7 \%$ and $12.8 \%$, respectively, compared to CK treatment. The boll number per plant in the HA5 treatment was significantly higher than those in the other six treatments $(P<0.05)$ (Fig. 5a). Boll number of HA1, HA2, HA3, HA4, HA5 and HA6 increased $8.6 \%, 9.4 \%, 16.7 \%, 15.2 \%, 24.5 \%$ and $15.9 \%$, respectively, compared to CK treatment. Seed cotton yield in the HA5 treatment was significantly higher than those in the other six treatment $(P<0.05)$ (Fig. $5 b)$. Seed cotton yield of HA1, HA2, HA3, HA4, HA5 and HA6 increased 13.3\%, 19.7\%, 23.4\%, 24.8\%, 37.2\% and 26.8\% (Fig. 5c), compared to CK treatment. Water use efficiency of HA1, HA2, HA3, HA4, HA5 and HA6 increased $14.8 \%, 15.5 \%, 14.0 \%, 15.5 \%, 23.4 \%$ and $16.9 \%$, compared to CK treatment (Table 7).
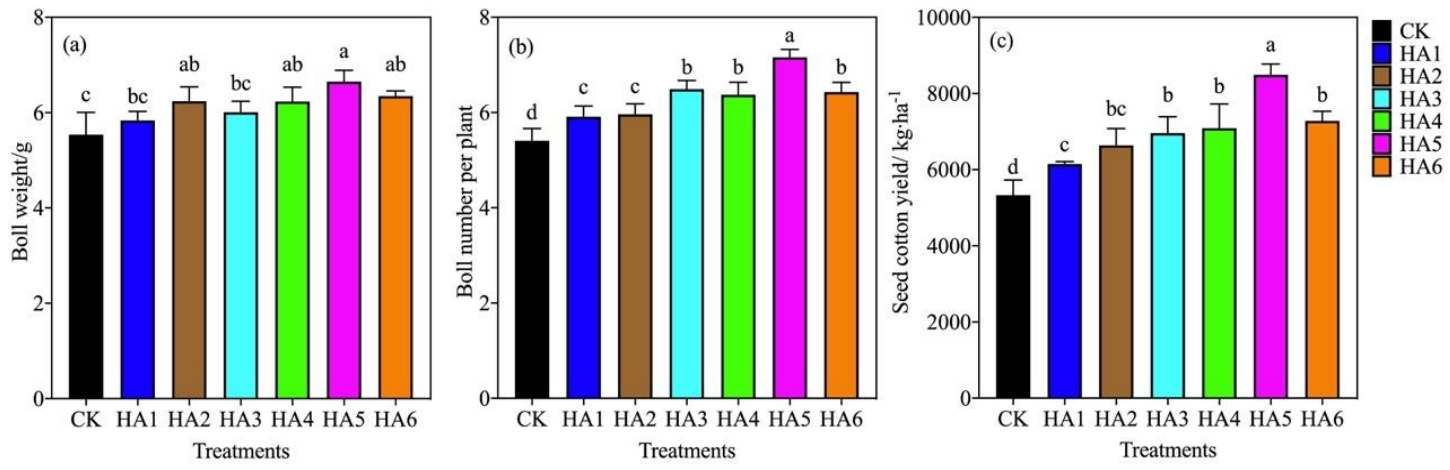

Figure 5. Effects of different amounts of potassium humate on the boll weight, boll number and seed cotton yield. Bars are the means + one standard error of the mean $(n=3)$. Different letters above the bars indicate a significant difference at $P<0.05$ according to an LSD test

Table 7. Water use efficiency and yield of cotton under different potassium humate treatments

\begin{tabular}{|c|c|c|c|c|c|c|}
\hline $\begin{array}{l}\text { Potassium } \\
\text { humate } \\
\text { treatment }\end{array}$ & $\underset{(\mathbf{m m})}{\mathbf{P}}$ & $\mathbf{I}(\mathbf{m m})$ & $\Delta \mathbf{W}(\mathbf{m m})$ & $\mathbf{E T}_{\mathbf{c}}(\mathbf{m m})$ & $Y\left(k g \cdot h a^{-1}\right)$ & WUE $\left(\mathrm{ka}^{\prime} \cdot \mathrm{ha}^{-1} \cdot \mathrm{mm}^{-1}\right)$ \\
\hline $\mathrm{CK}$ & 64.4 & 487.5 & $68.1 \pm 6.3 \mathrm{a}$ & $620.0 \pm 6.3 \mathrm{a}$ & $6058.2 \pm 366.8 \mathrm{c}$ & $9.8 \pm 0.5 c$ \\
\hline HA1 & 64.4 & 487.5 & $44.7 \pm 4.2 b$ & $596.6 \pm 4.2 b$ & $6859.4 \pm 262.4 b$ & $11.5 \pm 0.4 b$ \\
\hline HA2 & 64.4 & 487.5 & $47.3 \pm 3.5 b$ & $599.2 \pm 3.5 b$ & $6942.7 \pm 398.3 \mathrm{ab}$ & $11.6 \pm 0.6 \mathrm{~b}$ \\
\hline HA3 & 64.4 & 487.5 & $44.9 \pm 2.5 b$ & $596.8 \pm 2.5 b$ & $6776.1 \pm 446.7 \mathrm{~b}$ & $11.4 \pm 0.7 b$ \\
\hline HA4 & 64.4 & 487.5 & $43.9 \pm 3.3 b$ & $595.8 \pm 3.3 b$ & $6921.6 \pm 412.2 \mathrm{ab}$ & $11.6 \pm 0.6 b$ \\
\hline HA5 & 64.4 & 487.5 & $46.6 \pm 3.5 b$ & $598.5 \pm 3.5 b$ & $7653.2 \pm 570.0 \mathrm{a}$ & $12.8 \pm 0.9 \mathrm{a}$ \\
\hline HA6 & 64.4 & 487.5 & $63.9 \pm 4.0 \mathrm{a}$ & $615.8 \pm 4.0 \mathrm{a}$ & $7277.3 \pm 262.3 \mathrm{ab}$ & $11.8 \pm 0.4 \mathrm{ab}$ \\
\hline
\end{tabular}

Data are mean of the three replicates. The different letters indicate significant differences between treatments at $\mathrm{P}<0.05$ level according to the LSD test; the same letters are not significantly different at $\mathrm{P}>0.05$ level according to the LSD test

The relationship between potassium humate application and seed cotton yield could be described with a quadratic curve (Fig. 6); thus, a quadratic regression equation was 
established (Table 8). Seed cotton yield did not increase under a potassium humate application level of $30 \mathrm{~kg} \cdot \mathrm{ha}^{-1}$.

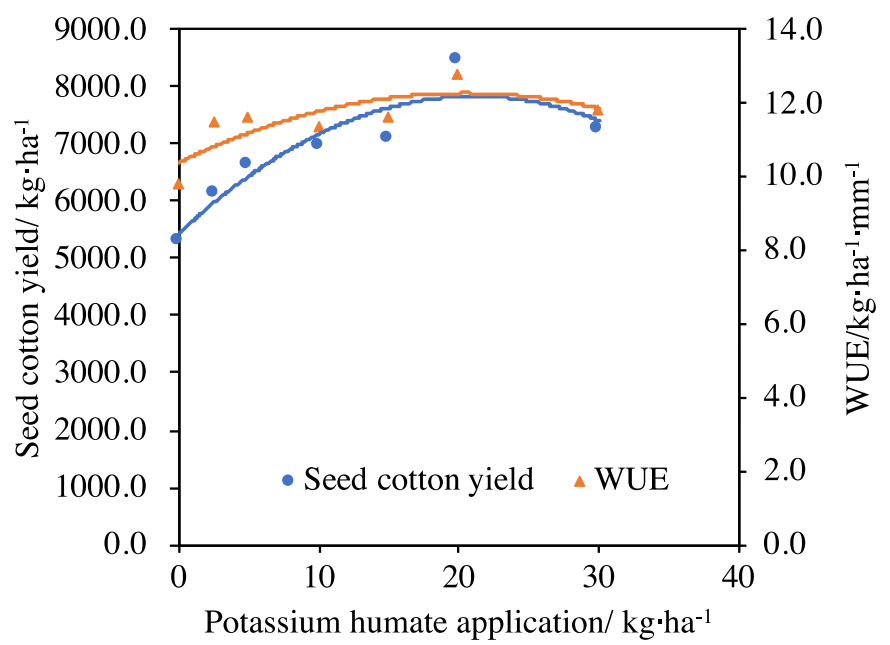

Figure 6. Relationships between seed cotton yield, irrigation water use efficiency and potassium humate application

Table 8. Regression equations between potassium humate application, seed cotton yield, and WUE

\begin{tabular}{c|c|c}
\hline Response variable $\mathbf{Y}$ & Regression equation & $\mathbf{R}^{2}$ \\
\hline Seed cotton yield/Y1 & $\mathrm{Y} 1=-5.3724 \mathrm{X}^{2}+226.87 \mathrm{X}+5446.2$ & $\mathrm{R}^{2}=0.85$ \\
WUE/Y2 & $\mathrm{Y} 2=-0.0045 \mathrm{X}^{2}+0.1847 \mathrm{X}+10.392$ & $\mathrm{R}^{2}=0.64$ \\
\hline
\end{tabular}

\section{Discussion}

Dry (arid and semi-arid) and soil saline regions are characterized by water scarcity. In these regions, saving irrigation water and sustainable soil use with no significant loss of crop yield is an urgent necessity. Studies have demonstrated that the potassium humate application can enhance plant growth and production and salinity control of the rhizosphere (Liang et al., 2007; Imbufe et al., 2005), and our results concur with those findings. Our results showed that application of potassium humate at 2.5, 5, 10, 15, 20, and $30 \mathrm{~kg} \cdot \mathrm{ha}^{-1}$ could improve seed cotton yield by $13.3 \%, 19.7 \%, 23.4 \%, 37.2 \%$ and $26.8 \%$, respectively, and increase, WUE by $14.8 \%, 15.5 \%, 14.0 \%, 15.5 \%, 23.4 \%$ and $16.9 \%$, compared to $\mathrm{CK}$ treatment (Table 6). The average amount of irrigation for all treatments (CK, HA1, HA2, HA3, HA4, HA5 and HA6) was $487.5 \mathrm{~mm}$ during the entire cotton growing season. High seed cotton yield in potassium humate treatments was 6859.4-7653.2 $\mathrm{kg} \cdot \mathrm{ha}^{-1}$. Correspondingly, high water use efficiency was 9.8$12.8 \mathrm{ka} \cdot \mathrm{ha}^{-1}$. In contrast, the amount of irrigation required by local farmers was approximately $600 \mathrm{~mm}$ during the entire cotton growing season, and the seed cotton yield obtained (without using potassium humate in field) was about $6700 \mathrm{~kg} \cdot \mathrm{ha}^{-1}$. Thus, the water use efficiency of local farmers was $11.1 \mathrm{~kg} \cdot \mathrm{ha}^{-1}$. Compared to the local irrigation practice without potassium humate, water use efficiency applied potassium humate in the cotton field was 1.15 times higher. The application of potassium humate could save up to $13 \%$ water. Grant et al. (2017) showed that cotton yield decreased with 
apparent over-irrigation in soil with low water holding capacity. Therefore, local farmers who did not have access to efficient water irrigation system obtain lower than optimal cotton yield. Thus, we recommended that local farmers use potassium humate in the cotton field to save irrigation water and achieve optimal cotton yield.

The soil with well-stabilized soil aggregates structure had the excellent ability to storing nutrients and soil water (Angers et al., 1992; Liang and Shi, 2020). In current study, potassium humate significantly increased the proportion of soil macroaggregates, which implied potassium humate could promote the formation of macroaggregates in saline soil under film mulched drip irrigation. Similar results were also found by Mostafa (2011). Bongiovanni and Lobartini (2006) reported that humic matter, considered as a persistent cementing agent, is involved in stabilizing microaggregates. These microaggregates are bound into macroaggregates, due to the effect of transient binding agents (polysaccharides derived from plants and microorganisms and temporary binding agents (fungal hyphae, fine roots, bacterial cells) (Tisdall and Oades, 1982; Odades, 1993). Particulate organic matter (POM) improves the soil aggregation since it can form an organic core surrounded by clay, silt particles, and aggregates (Six et al., 2004). This was an explanation that potassium humate resulted in the increase of macroaggregates. In the saline alkaline soil, $\mathrm{Ca}^{2+}$ is gradually replaced by $\mathrm{Na}^{+}$at soil exchangeable sites, which process caused degradation of soil structure (Dai et al., 2019). Wu et al. (2021) reported that the correlation between exchangeable $\mathrm{Ca}$ and MWD was positive, and the correlation between exchangeable $\mathrm{Na}^{+}$and MWD was negative. In this study, greater MWD was in the treatments with potassium humate rather than $\mathrm{CK}$, suggesting that saline potassium humate improved the stability of water-stable aggregates.

Liu et al. (2020) reported that humic acid improved could reshape the microstructure of macroaggregates by replenishing organic matter, which enhanced salt leaching. In current study, the salt accumulation rate of none application of potassium humate on the balance with $0-40 \mathrm{~cm}$ and $0-100 \mathrm{~cm}$ soil layer in brackish water irrigation treatment was higher than potassium humate treatments (Table 3). The HA6 treatment could leach the soil salinity with $40 \mathrm{~cm}$ soil layer.

The potassium humate application played an important role in decreasing the soil salinity, improving seed cotton yield, and water use efficiency. The optimal application amount of potassium humate requires taking these components into account. In experiments presented here, the relationship between cotton yield and the amount of potassium humate and between WUE and the amount of potassium humate followed quadratic curves (Fig. 6). The determinate coefficients of the curves were 0.85 and 0.64 for cotton yield and WUE, respectively. The potassium humate production function (Fig. 6) for different treatments showed that the highest yield and WUE were obtained at a potassium humate amount of $21.1 \mathrm{~kg} \cdot \mathrm{ha}^{-1}$ and $20.5 \mathrm{~kg} \cdot \mathrm{ha}^{-1}$, respectively.

\section{Conclusions}

Our findings indicate that in saline soils, application of potassium can improve cotton growth, yields, water use efficiency while at the same time potentially reducing salt accumulation and improving soil macro-aggregates. The highest seed cotton yield and water use efficiency was obtained at potassium humate application amounts of $20 \mathrm{~kg} \mathrm{ha}^{-1}$ in this study. The highest salt leaching efficiency was obtained at potassium humate application amount of $30 \mathrm{~kg} \cdot \mathrm{ha}^{-1}$ in this study. The accumulation of salt was 
very small at potassium humate application amount of $20 \mathrm{~kg} \cdot \mathrm{ha}^{-1}$. According to the results of regression equation between seed cotton yields, water use efficiency and potassium humate application amount, the highest yield and WUE were obtained at a potassium humate amount of $21.1 \mathrm{~kg} \cdot \mathrm{ha}^{-1}$ and $20.5 \mathrm{~kg} \cdot \mathrm{ha}^{-1}$, respectively. The potassium humate application amount of $20.5 \mathrm{~kg} \cdot \mathrm{ha}^{-1}$ was recommended as an optimal potassium humate amount of saline soils from the point of view of water saving. The potassium humate application amount of $30 \mathrm{~kg} \cdot \mathrm{ha}^{-1}$ was recommended as an optimal potassium humate amount of saline soils from the point of view of improving soil quality. Exploring the physiological and ecological functional potential of potassium humate has great theoretical and practical importance for improvement of saline soil and increasing agricultural efficiency. Collectively, the results of this research might encourage farmers to include potassium humate in their soil management practices due to the enhanced yield observed in the present study. However, effects of potassium humate on the relationship between seed cotton yield, nutrient uptake and nutrient use efficiency under brackish water irrigation need to be further evaluated.

Acknowledgements. This work was supported by the key program by the National Natural Science Foundation of China (grant number 41830754) and the National Nature Science Foundation of China (grant number 51679190, 41907010).

\section{REFERENCES}

[1] Ahmed I. A., Ahmed S. E., Mohamed, K. A., EI-Sayed, M. D., Li, H. T., Wang, L. Q. (2020): Mitigating nitrate accumulation in potato tubers under optimum nitrogen fertilization with k-humate and calcium chloride. - Journal of Cleaner Production 259: 121108.

[2] Angers, D. A. (1992): Changes in soil aggregation and organic carbon under corn and alfalfa. - Soil Science Society of America Journal 56(4): 1244-1249.

[3] Bongiovanni, M. D., Lobartini, J. C. (2006): Particulate organic matter, carbohydrate, humic acid contents in soil macro- and microaggregates as affected by cultivation. Geoderma 136(3-4): 660-665.

[4] Dai, H. C., Chen, Y. Q., Liu, K. C., Li, Z. X., Qian, X., Zang, H. D., Yang, X. L., Zhao, Y. X., Shen, Y. W., Li, Z. J., Sui, P. (2019): Water-stable aggregates and carbon accumulation in barren sandy soil depend on organic amendment method: a three-year field study. - Journal of Cleaner Production 212: 393-400.

[5] Du, J. R., Zhang, X., Feng, X., Wu, Y., Ali, M. E. A. (2020): Desalination of high salinity brackish water by an NF-RO hybrid system. - Desalination 491: 114445.

[6] Fang, S., Tu, W., Mu, L., Sun, Z., Yang, Y. (2019): Saline alkali water desalination project in southern Xinjiang of China: a review of desalination planning, desalination schemes and economic analysis. - Renewable and Sustainable Energy Reviews 113: 109268.

[7] Grant, T. J., Leib, B. G., Savoy, H. J., Verbree, D. A., Haghverdi, A. (2017): Cotton response to irrigation and nitrogen source in differing mid-south soils. - Agronomy Journal 109(6): 2537-2544.

[8] Imbufe, A. U., Patti, A. F., Burrow, D., Surapaneni, A., Jackson, W. R., Milner, A. D. (2005): Effects of potassium humate on aggregate stability of two soils from Victoria, Australia. - Geoderma 125(3-4): 321-330.

[9] Izhar, S. M., Adnan, M., Fahad, S., Wahid, F., Khan, A., Yue, Z., Subhan, D., Muhammad, Z. H., Martin, B., Rahul, D. (2020): Application of single superphosphate 
with humic acid improves the growth, yield and phosphorus uptake of wheat (Triticum aestivum L.) in calcareous soil. - Agronomy 10: 1224.

[10] Khaled, H., Hassan, A. F. (2011): Effect of different levels of humic acids on the nutrient content, plant growth, and soil properties under conditions of salinity. - Soil and Water Research 6(1): 21-29.

[11] Khan, A., Wang, L., Ali, S., Tung, S. A., Hafeez, A., Yang, G. Z. (2017): Optimal planting density and sowing date can improve cotton yield by maintaining reproductive organ biomass and enhancing potassium uptake. - Field Crop Research 214: 164-174.

[12] Kuang, W., Gao, X., Gui, D., Tenuta, M., Flaten, D. N., Yin, M., Zeng, F. J. (2018): Effects of fertilizer and irrigation management on nitrous oxide emission from cotton fields in an extremely arid region of northwestern China. - Field Crop Research 229: 1726.

[13] Kumar, J. S., Ramatshaba, T. S., Wang, G., Liang, Y., Liu, H., Gao, Y., Duan, A. (2020): Response of growth, yield and water use efficiency of winter wheat to different irrigation methods and scheduling in North China Plain. - Agricultural Water Management 217: 292-302.

[14] Lakhdar, A., Rabhi, M., Ghnaya, T., Montemurro, F., Jedidi, N., Abdelly, C. (2009): Effectiveness of compost use in salt-affected soil. - Journal of Hazardous Materials 171: 29-37.

[15] Li, J. G., Pu, L. J., Zhu, M., Zhang, J., Li, P., Dai, X. Q., Xu, Y., Liu, L. L. (2014): Evolution of soil properties following reclamation in coastal areas: a review. - Geoderma 226: 130-139.

[16] Liang, J. P., Shi, W. J. (2020): Poly- $\gamma$-glutamic acid improves water-stable aggregates, nitrogen and phosphorus uptake efficiency, water-fertilizer productivity, and economic benefit in barren desertified soils of Northwest China. - Agricultural Water Management 245: 106551.

[17] Liang, T. B., Wang, Z. L., Wang, R. J., Liu, L. L., Shi, Y. C. (2007): Effect of potassium humate on ginger root growth and its active oxygen metabolism. - Chinese Journal of Applied Ecology 18(4): 813-817.

[18] Liu, M. L., Wang, C., Liu, X. L., Lu, Y. C., Wang, Y. F. (2020): Saline-alkali soil applied with vermicompost and humic acid fertilizer improved macroaggregate microstructure to enhance salt leaching and inhibit nitrogen losses. - Applied Soil Ecology 156: 103705.

[19] Mahmoodi-Eshkaftaki, M., Rafiee, M. R. (2020): Optimization of irrigation management: a multi-objective approach based on crop yield, growth, evapotranspiration, water use efficiency and soil salinity. - Journal of Cleaner Production 252: 119901.

[20] Mcmaster, G. S., Wilhelm, W. W. (1997): Growing degree-days: one equation, two interpretations. - Agricultural \& Forest Meteorology 87(4): 291-300.

[21] Mostafa., M. R. (2011): Effects on growth, yield, and fruit quality in tomato (Lycopersicon esculentum Mill.) using a mixture of potassium humate and farmyard manure as an alternative to mineral-N fertilizer. - Journal of Horticultural Science Biotechnology 86(3): 249-254.

[22] Nan, L., Guo, Q., Cao, S. (2020): Archaeal community diversity in different types of saline-alkali soil in arid regions of Northwest China. - Journal of Bioscience and Bioengineering 130: 382-389.

[23] Nie, X. D., Li, Z. W., Huang, J. Q., Liu, L., Xiao, H. B., Liu, C., Zeng, G. M. (2018): Thermal stability of organic carbon in soil aggregates as affected by soil erosion and deposition. - Soil Tillage Research 175: 82-90.

[24] Ning, S. R., Zhou, B. B., Shi, J. C., Wang, Q. J. (2020): Soil water/salt balance and water productivity of typical irrigation schedules for cotton under film mulched drip irrigation in northern Xinjiang. - Agricultural Water Management 245: 106651.

[25] Oades, J. M. (1993): The role of biology in the formation, stabilization and degradation of soil structure. - Geoderma 56: 377-400. 
[26] Ouni, Y., Ghnaya, T., Montemurro, F., Abdelly, C., Lakhdar, A. (2014): The role of humic substances in mitigating the harmful effects of soil salinity and improve plant productivity. - International Journal of Plant Production 8: 353-374.

[27] Rath, K. M., Rousk, J. (2015): Salt effects on the soil microbial decomposer community and their role in organic carbon cycling: a review. - Soil Biology Biochemistry 81: 108123.

[28] Rath, K. M., Fierer, N., Murphy, D. V., Rousk, J. (2019): Linking bacterial community composition to soil salinity along environmental gradients. - The ISME Journal 13: 836846.

[29] Saidimoradi, D., Ghaderi, N., Javadi, T. (2019): Salinity stress mitigation by humic acid application in strawberry (Fragaria $x$ ananassa Duch.). - Scientia Horticulturae 256: 108594.

[30] Sekhon, K. S., Kaur, A., Thaman, S., Sidhu, A. S., Garg, N., Choudhary, O. P., Buttar, G. S., Chawla, N. (2020): Irrigation water quality and mulching effects on tuber yield and soil properties in potato (Solanum tuberosum L.) under semi-arid conditions of Indian Punjab. - Field Crops Research 247: 107544.

[31] Shareef, M., Gui, D. W., Zeng, F. J., Waqas, M., Zhang, B., Iqbal, H. (2018): Water productivity, growth, and physiological assessment of deficit irrigated cotton on hyperarid desert-oases in Northwest China. - Agricultural Water Management 206: 1-10.

[32] Sheehy, J., Regina, K., Alakukku, L., Six, J. (2015): Impact of no-till and reduced tillage on aggregation and aggregate-associated carbon in Northern European agroecosystems. Soil Tillage Research 150: 107-113.

[33] Six, J., Bossuyt, H., Degryze, S., Denef, K. (2004): A history of research on the link between (micro)aggregates, soil biota, and soil organic matter dynamics. - Soil Tillage Research 79(1): 7-31.

[34] Tan, S. (2018): Study on soil water and salt regulation and cotton growth characteristics under film-mulched drip irrigation with brackish water. - Thesis, Xi'an University of Technology.

[35] Tan, S., Wang, Q. J., Zhang, J. H., Chen, Y., Shan, Y. Y., Xu, D. (2018): Performance of AquaCrop model for cotton growth simulation under film-mulched drip irrigation in southern Xinjiang, China. - Agricultural Water Management 196: 99-113.

[36] Tian, J. S., Zhang, X. Y., Yang, Y. L., Yang, C. X., Xu, S. Z., Zuo, W. Q., Zhang, W. F., Dong, H. Y., Jiu, X. L., Yu, Y. C., Zhao, Z. (2017): How to reduce cotton fiber damage in the Xinjiang China. - Industrial Crops and Products 109: 803-811.

[37] Tisdall, J. M., Oades, J. M. (1982): Organic matter and water-stable aggregates in soils. European Journal of Soil Science 33: 141-163.

[38] USDA (2020): Natural Resources Conservation Service, United States Department of Agriculture. Web Soil Survey. - https:// websoilsurvey.sc.egov.usda.gov/.

[39] Wang, H. D., Wu, L. F., Cheng, M. H., Fan, J. L., Zhang, F. C., Zou, Y. F., Chau, H. W., Gao, Z. J., Wang, X. K. (2018): Coupling effects of water and fertilizer on yield, water and fertilizer use efficiency of drip-fertigated cotton in northern Xinjiang, China. - Field Crops Research 219: 169-179.

[40] Watson, D. J. (1937): The estimation of leaf area in field crops. - The Journal of Agricultural Science 27(3): 474-483.

[41] Watts, D. B., Runion, G. B., Balkcom, K. S. (2017): Nitrogen fertilizer sources and tillage effects on cotton growth, yield, and fiber quality in a coastal plain soil. - Field Crops Research 201: 184-191.

[42] Wu, L. P., Zhang, S. R., Ma, R. H., Chen, M. M., Wei, W. L., Ding, X. D. (2021): Carbon sequestration under different organic amendments in saline-alkaline soils. - Catena 196: 104882.

[43] Zhang, Q., Zhou, W., Liang, G. Q., Sun, J. W., Wang, X. B., He, P. (2015): Distribution of soil nutrients, extracellular enzyme activities and microbial communities across 
particle-size fractions in a long-term fertilizer experiment. - Applied Soil Ecology 94: 5971.

[44] Zhao, T., Deng, X., Xiao, Q., Han, Y., Chen, J. (2020): Iaa priming improves the germination and seedling growth in cotton (Gossypium hirsutum L.) via regulating the endogenous phytohormones and enhancing the sucrose metabolism. - Industrial Crops and Products 155: 112788.

[45] Zheng, H., Wang, X., Chen, L., Wang, Z. Y., Xia, Y., Zhang, Y. P., Wang, H. F., Luo, X. X., Xing, B. S. (2018): Enhanced growth of halophyte plants in biochar-amended coastal soil: roles of nutrient availability and rhizosphere microbial modulation. - Plant, Cell \& Environment 41: 517-532.

[46] Zhou, X., Wang, R., Gao, F., Xiao, H., Xu, H., Wang, D. (2019): Apple and maize physiological characteristics and water-use efficiency in an alley cropping system under water and fertilizer coupling in Loess Plateau, China. - Agricultural Water Management 221: 1-12. 